\title{
THE EUROPEAN STABILITY MECHANISM AND THE IMF: FROM ENHANCED COOPERATION TO EMBEDDED SUPERVISOR"
}

\author{
Cameron Climie \\ Carleton University
}

\begin{abstract}
This paper examines the role played by the International Monetary Fund (IMF) in the European Stability Mechanism (ESM), finding that the ESM has greatly expanded the IMF's surveillance and oversight roles in the European Monetary Union (EMU). Building from a liberal intergovernmental framework of integration analysis, this paper argues that the IMF's function as a de facto EMU supervisor in the ESM, a significant break from prior European integration, stems from the alignment of crisis response preferences amongst the EMU's largest economies, the erosion of the credibility of the European Commission as an enforcer of structural reforms, and the IMF's close fit with the preferred institutional arrangements that derived from the bargaining dynamics between euro members.
\end{abstract}




\section{Introduction}

During the negotiation of the Treaty of Maastricht, the European Commission undertook workinglevel discussions with the staff of the International Monetary Fund (IMF) to determine what changes, if any, the creation of a common currency would have on the IMF's mandate and operations. However, in the face of significant opposition from the most powerful member governments in the European Union (EU) (particularly the United Kingdom), the IMF's relationship with its European members saw little change as a result of the euro: economic surveillance remained rooted at the state level, and the IMF was not given an expanded role in the oversight of the European economy. What supervisory powers were created were delegated to the European Commission, through both the Stability and Growth Pact (SGP) and Broad Economic Policy Guidelines (BEPGs).

However, the euro area debt crisis has fundamentally changed the nature of the IMF's relationship with the European Monetary Union (EMU). After partnering with the Commission and the European Central Bank (ECB) to administer ad-hoc bailout funds in the early 2010s, the 2012 European Stability Mechanism (ESM) codified a significant oversight role for the IMF in the European economy. Under the terms of the ESM Treaty, the IMF's "active participation... will be sought, both at a technical and financial level," and the IMF now even provides input and oversight in cases where the Fund is not directly involved in lending to European governments (European Stability Mechanism 2012, 5). In effect, the IMF has become a de facto institution of macroeconomic oversight within the euro area.

Building from a liberal intergovernmental framework of integration analysis, this paper seeks to unpack the decision to integrate the IMF into the oversight and enforcement mechanisms of the ESM, ultimately arguing that shifts in the policy positions and relative bargaining strength of EMU states - particularly an alignment amongst the euro area's core economies - broke prior resistance to incorporating an external agent into the EMU's governance structure. The decision to delegate significant oversight power to the IMF also stemmed from the Commission's own lack of credibility following the failure of the SGP to constrain public spending in the euro area, and from the incrementalist approach of European policy evolution. This paper will be divided into four sections. In the first, I will outline the nature of the changes to the IMF-EMU relationship created by the ESM. In the second, I will provide a brief outline of Liberal Intergovernmental (LI) theory's three-stage process analysis, before exploring, in the third, the factors at each stage that shaped the decision to incorporate the IMF into European governance. In the fourth, I will outline a number of implications of the IMF's new role for our understanding of European governance and the future of EMU oversight.

\section{From Hungary to Greece}

Prior to the outbreak of the euro area crisis, the relationship between the IMF and the organs of EMU governance was minimal. The IMF's annual consultations with member states (Article IV) had remained rooted at the state level, despite attempts in the 1990s to expand the IMF's oversight role in the euro area; the IMF undertook informal annual discussions with the Commission, and the ECB held observer status on the IMF Executive Board for issues related to the European economy (Broome 2013, 600). However, supervisory power in the euro area was invested in the Commission, albeit in policy instruments that often lacked teeth in the fight to constrain national debt and public deficits (Hodson 2011, 31). 
When the collapse of Lehman Brothers triggered an international liquidity crisis in October 2008, both the EU and IMF moved to intervene in affected economies. Lending to Hungary, Latvia, and Romania in autumn 2008 worked according to the pre-crisis institutional model, with the EU and IMF relying on separate policy conditions, sequencing of loan tranches, staff missions, and monitoring mechanisms (Hodson 2015, 578). However, each lending programme also demonstrated an increasing degree of collaboration between the IMF and the Commission medium-term assistance to Hungary made disbursement of future EU loan tranches contingent on meeting the IMF's reform requirements, while staff from both institutions were involved in drafting Romania's budgetary management laws in December (Lutz and Kranke 2014, 311). Collaboration between the IMF, ECB, and Commission was further deepened by Greece's financial collapse in October 2009 and the spread of fears around public debt to other European economies (Mayer 2012, 107). When Greece requested emergency financing in April 2010, the level of cooperation between the IMF and EMU increased dramatically; rather than build separate lending programmes, the IMF, Commission, and ECB negotiated a single $\$ 145$ bn lending facility for the Greek government (Joyce 2013, 183). Programme monitoring was conducted jointly, and each of the three institutions was delegated specific powers in the Loan Facility Agreement. While the euro institutions were invited to report on compliance, the IMF's surveillance reports were heavily drawn upon, and Eurogroup agreements to disburse further loans to Greece were made on the basis of joint Commission-IMF analysis (Eurogroup 2011).

In May 2010, European lending operations were further expanded by a pair of ad-hoc lending facilities that "embodied two distinctive approaches to programme monitoring" and the role of the IMF in overseeing EMU lending (Hodson 2015, 579). The first, the European Financial Stability Mechanism (EFSM), tasked the Commission with verifying that recipient states were complying with fiscal policy conditions placed on lending programmes, but did so noting that such lending would be "in the context of a joint EU/International Monetary Fund support" (ibid., 580). By contrast, the European Financial Stability Facility (EFSF) vested the delegation of surveillance and enforcement with euro area members. In practice, this meant mimicking the approach taken by the Greek lending programmes: the Troika's members conducted joint reviews of programme compliance as part of joint IMF-EMU financing (ibid., 579-580). Whether formally or informally, the first structured systems of crisis lending and policy enforcement in the aftermath of the euro area debt crisis relied upon a much closer IMF-EMU relationship than that envisioned by the Maastricht Treaty.

In February 2012, the EMU's nineteen members signed the Treaty Establishing the European Stability Mechanism, creating a permanent $€ 500$ billion bailout facility. Like the EFSF, the ESM "can lend to countries to fund adjustment programmes, give 'precautionary financial assistance' to countries in the form of a credit line, help in recapitalizing banks in EMU member countries and intervene in the primary and secondary government bond markets" (Mayer 2012, 147). Significantly, the ESM served to create a formal, embedded role for the IMF in supranational economic surveillance, both as a lending institution and for broader macroeconomic oversight; the ESM offered "the most explicit statement to date of the IMF's de facto role in EU monitoring" (Hodson 2015, 580). The ESM states in Article 13 that "the Commission, in liaison with the ECB and, wherever possible, together with the IMF, shall be entrusted with monitoring compliance with the conditionality attached to the financial assistance facility [emphasis mine]" (European Stability Mechanism 2012, 29). Rather than the IMF simply acting as a co-lender, the ESM established it as a monitor of compliance with the policy conditions attached to emergency lending, and as an 
advisor "on the design, implementation and monitoring of the fiscal adjustments and structural reforms that the afflicted nations undertook" (Rato 2011, 89).

Yet, the ESM's framework of IMF involvement went well beyond that of the EFSF or EFSM; even in cases where the IMF was not a co-lender, the wording of the ESM Treaty enabled the Fund to be involved in joint review missions with the Commission and ECB. Indeed, the ESM requires agreement between the European Council of Finance Ministers (ECOFIN) and the IMF Executive Board on the specifics of loan arrangements and policy reforms (Lutz and Kranke 2014, 313). The case of Spain is the most notable: in June 2012, Spain requested financial assistance from the EFSF (and later the ESM) to recapitalize its debt-ridden banking sector. Though financing the effort fell primarily to the ECB, the IMF was involved in the initial assessment of the Spanish banking sector, and concluded that Spain met the requirements for lending assistance (European Council 2012, 12). During the disbursement of funds, the IMF conducted four independent monitoring missions on the implementation of banking sector reforms, and produced a final report for the European Commission in November 2013, assessing reform progress. These missions occurred outside of the IMF's Article IV process of bilateral surveillance. Similarly, the IMF has continued to engage in oversight and programme review in Greece, even though its participation in subsequent rounds of financial assistance has been in question since 2015; EU officials have insisted on IMF participation in the most recent tranches of lending, even in the face of significant disagreements among the Troika institutions over the sustainability of Greek austerity measures (Spiegel and Chazan 2016).

While the IMF's role in pre-ESM bailouts could be attributed to the need for oversight of its own lending, the experience of Spain suggests an evolving role for the IMF in euro area oversight. Even when not acting as a co-lender, the Fund now exists as a de facto EMU institution. This integration of the IMF into euro area governance represents a significant departure from the prior preferences of EU and EMU member states, who have preferred to keep governance functions 'in-house' in institutions under their control. Indeed, when the IMF and Commission had undertaken exploratory talks in 1993-94 on the possibility of a closer relationship between the IMF and EU, both France and Germany had vocally opposed delegating additional powers to an external institution. To understand this switch in time by the EMU's most powerful members, we must examine the dynamics of bargaining and state preferences during the negotiation of the ESM, and how these preferences manifested themselves in the delegation of supranational competences.

\section{State Preferences and Bargaining Dynamics of the ESM}

When the possibility of enhanced EU-IMF cooperation was first raised in the 1990s, proposals were scuttled by opposition from key European members of the IMF Executive Board - most notably, Germany and the UK. As such, the most likely explanation for the evolution of that relationship is a shift in state preferences on EU-IMF cooperation. To analyze those preferences, this paper builds from a liberal intergovernmental framework of integration analysis. Formulated by Andrew Moravcsik in the late 1980s and early 1990s, liberal intergovernmentalism (LI) sees the deepening and broadening of supranational integration as the product of interstate bargaining based on the policy preferences of domestic political and economic actors. Rather than seeing integration as the product of a pan-European elite, LI argues that integration stems from rational bargaining choices based on the potential for gains from policy coordination and delegation (Moravcsik 1993, 495-496). 
In analyzing the EU, LI treats economic integration as a three-stage process. In the first, national governments construct policy preferences on the basis of input from domestic interest groups. Though Moravcsik identifies many possible inputs, LI presumes that industry interests will override civil society or domestic party politics on the terms of economic integration. In the second, states negotiate on the basis of those preferences, with the dynamics of negotiation influenced by the ability of states to unilaterally opt out of bargaining, build alternative coalitions to exclude recalcitrant governments, or seek consensus through trade-offs or side-payments (either financial or otherwise) to reluctant negotiating parties (Moravcsik 1993, 499-506). In the third, states delegate policymaking or enforcement authority to external agents; though states are reluctant to abrogate policymaking powers, they will do so if external institutions are deemed necessary to enforce commitments, in the case of incomplete intergovernmental contracts. When there are incentives to defect from agreements, states with strong preferences will push for institutional delegation as a means of "locking in" policy commitments (Moravcsik 1998, 69).

The formation of national preferences on the ESM and its associated treaty reforms (i.e., the Fiscal Compact) has been documented by both mainstream and academic commentary. As Schimmelfennig notes, the preferences of euro area members have been directly driven by a materialist, economic calculus that reflects "the macroeconomic preferences of ruling governmental coalitions" during the crisis $(2015,180)$. Much of this lay in the immediate, material nature of the crisis that framed the interests of producers, financial interests, interest groups, and political institutions in fundamentally economic terms. But these preferences also reflected the reality that economic factors were the key differentiation between euro area countries; the asymmetry of the crisis's effects stemmed from the asymmetry of economic policy strategies that had contributed to the crisis's onset. As Schimmelfennig notes, monetary union brought together a euro area 'core' - comprising central Europe and France - pursuing supply-side or export-led growth 'based on wage restraint, productivity, and competitiveness" and an EMU 'periphery' Iberia, Italy, Greece, and Ireland - pursuing demand-led growth reliant on fiscal expansion and wage inflation (Hall 2012, 358-359). Monetary union increased the divergence of those strategies, with southern European governments running larger current account and budget deficits while central Europe pursued ever more aggressive supply-side strategies (Schimmelfennig 2015, 180).

Euro member preferences were driven by a number of common factors that linked both core and periphery states. Chief among these were the high consequences of stagnation or euro area disintegration for all its members. For peripheral countries like Greece, dissolution would mean a sharp depreciation in the value of any replacement currency and a high possibility of sovereign default; for core members like Germany, dissolution meant the onset of a banking crisis (French and German banks held significant sovereign debt) and the steep appreciation of either national currencies or a successor regional currency (Lutz and Kranke 2014, 314). Consequently, all euro states had incentives to support integration policies that would prevent disintegration. However, the exact terms of policy integration were sharply contested by euro area members, reflecting a divergence of economic interests. Generally speaking, solvent countries preferred nationally-based fiscal adjustment policies (such as deficit reduction and policy reform), while indebted governments preferred mutualized adjustment (such as debt restructuring or Eurobonds). There are a number of specific state preferences worth identifying and unpacking.

Germany, as the state that would bear the heaviest financial burden of mutualized debt resolution, initially pushed to keep debt reduction nationalized. This preference was shared by Austria, Finland, and the Netherlands, who pushed for debt resolution that did not require fiscal 
commitments from solvent EMU members (Francis 2010). When it became clear that financial resources would be required to prevent the crisis from escalating further, Germany's position shifted towards favouring strict conditions on emergency financing, due to both the German public's opposition to financing what were seen as fiscally irresponsible periphery governments, and the deficit-averse economic orthodoxy that prevails among German, Dutch, and Austrian policy elites (Glencross 2014, 59).

Governments in the euro area's periphery - particularly those of Greece and Portugal - have favoured softer national adjustment targets, given the high economic and political costs of engaging in contractionary fiscal policy during demand-driven recessions. Indeed, Italy and Greece were among the first countries to support the creation of Eurobonds and a system of fiscal transfers between EMU countries (Reuters 2011). However, some indebted governments have also proven more willing to embrace strict conditionality, given that disintegration imposed even higher costs. France was ostensibly an outlier in policy preferences; though a significant contributor to both the EFSF/EFSM and ESM bailout funds, France supported the "Europeanization" of sovereign debt through a combination of Eurobonds, expansionist ECB monetary policy, and 'soft adjustment policies.' However, French preferences for mutualized debt resolution likely stemmed from French banks' high degree of exposure to Greek, Portuguese, Irish, and Spanish debt (Fuhrmans and Moffett 2010). Given that successive French governments have viewed the demands of loan conditionality as unsustainable, mutualized debt reduction was seen as the only means of guaranteeing the stability of the French financial economy. Thus, with the exception of France, state preferences on the structure of the euro area were firmly divided between solvent and insolvent states; though they were united by the prohibitively high costs of euro area disintegration, they disagreed significantly on how best to resolve the debt crisis.

In deepening the processes and policies of integration, interstate bargaining is shaped by the pursuit of the optimal strategies of member states that policy preferences and external constraints allow. Three new elements of interstate bargaining shaped negotiations over the ESM Treaty. First, as Schimmelfennig notes, the supranational bargaining environment was shaped by the prohibitively high stakes of negotiation failure; states had incentives to preserve the euro area, even if that meant compromising on specific short-term preferences $(2015,184-185)$. This risk was perhaps best encapsulated by German Chancellor Angela Merkel: "if the Euro fails, Europe fails" (Mayer 2012, 16). The scale of potential damage drove states to engage in hard bargaining, defined by Moravcsik as "credible threats to veto proposals, to withhold financial side-payments, and to form alternative alliances excluding recalcitrant governments" (Moravcsik 1998, 3). As Schimmelfennig notes, hard bargaining is most likely in circumstances with high stakes and a clear distribution of costs. For solvent governments, this meant withholding promises of financial assistance until indebted governments agreed to policy reforms; for indebted states, this meant invoking the reluctance of domestic interest groups to stomach unpopular reforms and delaying requests for financial assistance to exact better terms when debt panic escalated (Schimmelfennig 2015, 185-186). The high cost of failure also meant that EMU members had significant incentive to avoid the collapse of agreements, while also framing the consequences of negotiation failure in cataclysmic terms. In effect, euro members engaged in a game of "policy chicken": to engage in brinkmanship was smart strategy; to do so to the point where negotiations broke down was not.

The second important element of interstate bargaining was the asymmetry of interdependence within the euro area. While the consequences of disintegration were high for all euro members, the immediate consequences of withdrawal or ejection were far higher for indebted governments than 
creditor ones. This was particularly true for Germany's relationship with debtor governments. During the negotiation of the Maastricht Treaty and the SGP, Germany's economic position in the EU had been far weaker; still facing the high economic and financial costs of reunification, it lacked the material bargaining power to push for a system of hard enforcement mechanisms or credible checks on deficit spending that domestic interests demanded as the price for abandoning the deutschmark (Teschner 2000, 64, 70). By contrast, Germany in 2012 was characterized by strong economic growth and a position as the vital component of any EMU reforms that required significant financial resources.

However, Germany also lacked a credible alternative to the euro, meaning that unilateral withdrawal from negotiations over the ESM was unviable. While this precluded absolute leverage over negotiations, the scale of imbalance in the material terms of bargaining meant that Germany was able "to shape the terms of integration in return for giving up its opposition to bailing out insolvent Euro members" (Schimmelfennig 2015, 187). This meant that the outcomes of interstate bargaining reflected German preferences more than in the Maastricht Treaty or SGP; proposals for Eurobonds and debt mutualisation were both rejected, while financial assistance from solvent states was linked to strict fiscal austerity and extensive monitoring by supranational and international institutions for compliance (Glencross 2014, 59).

The final new factor that shaped ESM bargaining was the convergence of policy preferences among creditor economies. During negotiations over previous additions to the euro architecture, the exact terms of integration were often disputed between the most economically powerful states - in particular, between the German-Dutch axis and the French. Such divergences created incentives for states to bargain to the lowest common denominator, particularly on contentious issues like the enforcement of the SGP and BEPGs (Moravcsik 1993, 503). By contrast, the alignment of creditor country preferences in the early 2010 s created a voting bloc within ECOFIN sufficient to sway the course of negotiations. Even France, which favoured mutualized debt reduction and softer policy enforcement mechanisms than Germany, was sufficiently hampered by its own vulnerability to financial crisis to create a quiet, if begrudging, acceptance of German bargaining positions.

\section{Delegation to the IMF in the ESM Treaty: Credibility, Layering, and Institutional Structure}

It is the question of institutional delegation that is most pertinent to understanding the new role of the IMF in European economic governance. When considering the IMF's expanded role, both through explicit treaty language and deliberate ambiguity, three factors contributed to the delegation of competences to the IMF within the ESM Treaty.

The first factor that influenced the decision to incorporate the IMF into European governance was credibility - the input most readily identified by Moravcsik as the key determinant of states' willingness to delegate policymaking. Given the common interest in preserving the euro area, Schimmelfennig additionally notes that there was a common interest in creating institutional arrangements that would "enhance the commitment to the euro" (Schimmelfennig 2015, 190). However, the crisis cast doubt on the credibility of prior arrangements - particularly on questions of policy oversight and enforcement. Part of this gap was structural; as Rogers notes, the European Commission's ability to provide effective oversight stemmed from the contractual limitations on its ability to engage in crisis management, as Article 143 of the Maastricht Treaty prevented it and the ECB from providing emergency lending to euro area states (Rogers 2012, 208). However, the 
more salient analysis is provided by Hodson's 'multiple supervisor' variation on Jonas Tallberg's Principal-Agent-Supervisor framework. Tallberg (2003) argued that the EU's executive has historically acted as an institutional supervisor, tasked with ensuring that EU and EMU members comply with their own policy agenda; Hodson frames the addition of a second supervisor as a means of overcoming contractual difficulties with the initial monitor or preventing collusion between member states and institutions (Hodson 2015, 581-582).

The European Commission's implementation of the Stability and Growth Pact was both inconsistent and weak. Designed to prevent the accumulation of debt that sparked the crisis, the SGP has proven "malleable and, ultimately, toothless ahead of the financial crisis" (Schimmelfennig 2015, 189). Throughout the 2000s, the Commission routinely failed to enforce the SGP; only a handful of states were ever in full compliance with the limits on deficits and debt. Even when proceedings were initiated, the Commission proved flexible in its interpretation of deficit limits and restrained in its use of fiscal sanctions and similar enforcement mechanisms. Most damningly, the Commission routinely endorsed Greece's financial projections on deficit spending and public debt, which were found in October 2009 to have been repeatedly falsified (Panagiotarea 2013, 129-130).

The failure of the SGP compromised the Commission's credibility. Indeed, the failure of pre-crisis institutional arrangements called European governance into question more broadly. In March 2010, German Finance Minister Wolfgang Schäuble called for the creation of a "European Monetary Fund," which would function as a supranational version of the IMF, while both the French and Spanish governments preferred that crisis management remain a European matter. However, German Chancellor Angela Merkel ultimately concluded that euro area governance "lacked credibility"; coupled with the Commission's lack of expertise in crisis management, this necessitated drawing on external knowledge and institutions to fill the gap. By contrast, the IMF's credibility in crisis management and enforcement had been bolstered by its handling of the 2008 Financial Crisis; the Fund was widely praised for having acted "swiftly and decisively" to contain the spread of financial panic in East Europe and Central Asia. The IMF also had a long history of enforcing deeply unpopular policy reforms in South America and Southeast Asia, and was clearly perceived as a more credible monitor of policy reform than the Commission (Joyce 2013, 170171).

The second important factor was the question of path dependency. Institutional change can take one of three forms: incremental adjustments to policy, introduction of new policies, or radical changes to the overarching paradigms of policy discourse (Schwarzer 2015, 7). In the process of European integration, the general pattern has been one of layering - that is, building on prior policies and improving existing mechanisms, rather than engaging in fundamental paradigm shifts. Indeed, the very process of creating the euro confirms this: monetary union built on a series of exchange rate coordination schemes developed and improved throughout the preceding two decades, which themselves evolved from the complex fiscal transfers and monetary coordination needed to implement the Common Agricultural Policy (Tallberg 2003). This sequencing is often the result of collective learning, which occurs both nationally and supranationally as a result of inter-organizational deliberation, and different institutional perspectives processing similar information and experiences.

However, the previous architecture of euro governance was such that, when the debt crisis began, European leaders were confronted by an "empty toolbox": the ECB was statutorily barred from financing government debt, and the Commission had very little experience with crisis management 
- balance of payments support for European governments having ended with the ratification of the Maastricht Treaty. As Schwarzer notes, this left euro area leaders with four policy options in 2010: negotiate bilateral IMF loans to member states, package IMF lending with bilateral loans from other euro members, devise a crisis resolution mechanism that incorporated the IMF, or provide financial aid and crisis management without the IMF's involvement (Schwarzer 2015, 9). The first option proved unworkable; the scale of the crisis in Greece, and its threatened escalation to Italy and Iberia, was such that exclusively IMF lending could not stem market panic about euro area debt. Thus, initial lending to both EU and EMU governments occurred in line with the second option, with IMF and EU lending packaged into a series of ad hoc emergency financing mechanisms (the aforementioned EFSF and EFSM). By 2010, however, both Germany and France favoured the creation of a purely internal system for stemming the financial crisis. Yet by March 2010, "the debate on how to cope with liquidity crisis in the Euro area suddenly shifted towards an involvement of the IMF" (Schwarzer 2015, 10).

Several elements of the euro crisis made the creation of an EMF challenging. First, the debt crisis was characterized by high levels of volatility, rapid "and unstructured flows of information and high interaction among policymakers who shared the need to devise day-to-day interpretations of events" (Schwarzer 2015, 4). Given the rapidity with which the situation evolved and interpretations of events changed, solutions to the escalating debt crisis were needed quickly even when the worst of the initial crisis had been stemmed by the EFSF and EFSM. As a result, creating wholly new institutions was politically and mechanistically difficult, due both to the high degree of consensus required for European treaty modification and to the plodding nature of institutional creation - even if the crisis created the deep, systemic uncertainty that is often required for paradigmatic changes. Given that nearly a decade passed between the ECB's statutory founding and the full implementation of its mandate, starting from scratch was unworkable. That the Commission, European Council, and ECB's mechanisms were seen as "underdeveloped" in comparison to the IMF's reinforced the case for incorporating the Fund into governance structures.

Opting for the second best, yet more immediately feasible option was made more attractive by the nature of bureaucratic institutions; as Keohane notes, the belief in sunk costs means that modifying existing institutions and processes is often seen as easier than creating new ones. Bureaucracies also frequently engage in "satisficing" behaviour - embracing suboptimal policy solutions in the name of feasibility. Moreover, interpretations of the crisis that undermined the Commission's credibility as a monitor and enforcer meant that building entirely on existing euro area mechanisms was equally unworkable. As a result, integrating external systems and institutions was seen as the most workable option.

From the perspective of euro members, the IMF's history of crisis lending and oversight allowed for the best of both worlds. EFSF and EFSM lending and oversight policies were modelled on the IMF's own best practices, and the ESM used the IMF's policy model as a reference point for its own programme design (Schwarzer 2015, 13). Yet, integrating the IMF into European governance also stemmed from lessons learned about the reasons for the SGP's failure. The IMF offered a credible 'exit threat' - that is, the ability to simply withdraw from a lending programme - in a way that the Commission or ECB, with their constitutional obligation to promote the welfare of the euro area, could not. Indeed, the "political proximity" of the Commission to euro members was seen as a barrier to its fulfilling the mandate of economic surveillance and policy enforcement (Schwarzer 2015, 12). Moreover, the unpopularity of the Commission's enforcement of the SGP meant the IMF was a useful tool for 'policy laundering,' wherein the responsibility for unpopular 
decisions related to fiscal austerity was transferred to an external agent not reliant on the commitment of EMU members to the same extent as the Commission or ECB (Rogers 2012). Indeed, IMF scholars have often seen the Fund's role as one of scapegoating - enabling governments to blame an external actor for the domestic costs of unpopular or painful reforms (Vreeland 1999, 6). Thus, while the integration of the IMF into EMU governance represented a fundamental shift from the perspective of the Europeans, this was not the case for the IMF; rather, the Fund was fulfilling a useful policy role in Europe that it had historically served in both the Americas and Asia.

The third factor that influenced the decision to incorporate the IMF into EMU governance relates to the type of institutional structure that EMU members were seeking. Schimmelfennig notes that states are "more willing to centralize decision-making and delegate powers of monitoring and sanctioning" in the case of enforcement problems, "which produce incentives to defect unilaterally," as opposed to problems of coordination (which do not) $(2015,188)$. However, the euro crisis confronted its members with two enforcement problems: how to ensure insolvent states implemented reforms, and how to ensure creditor states committed to bailing out debtor governments. At face value, the centralization of enforcement power resolves both problems delegate to a credible enforcer, and centralize control of emergency lending to prevent reluctant creditor governments from opting out. However, the asymmetry of bargaining power meant that decisions around supranational delegation and enforcement were unbalanced. Throughout negotiation of the EFSF, EFSM, and ESM, Germany and other creditor countries "sought to limit their own financial commitments, but to strengthen the credibility of indebted countries' commitment to fiscal policy" (Schimmelfennig 2015, 189). In such cases, LI predicts that institutional choice would reflect a pattern wherein institutions responsible for overseeing financial assistance would preserve more state power than institutions of enforcement and supervision Germany would have the ability to opt out, while Greece would not.

It is in this dynamic of institutional choice that the delegation of enforcement and oversight powers to the IMF becomes clearest. Critically, the structure of the IMF's governance and operation aligns with the predicted pattern of institutional design. The Fund retains significant autonomy in its conduct of economic surveillance, both due to the highly technical nature of its work, and also because such work largely occurs at the staff level. However, major decisions regarding the design of lending programmes, including required reforms and the flexibility of conditionality, require $85 \%$ consensus on the Executive Board. Particularly from Germany's perspective, the ability of Fund members to design and oversee the conditions attached to emergency lending was attractive. As Chwieroth (2008) notes, there is a long-held view that German opposition to an IMF programme is sufficient to prevent Executive Board consensus (even if Germany lacks the formal veto power of the United States' voting shares). As a result, delegation to the IMF came to be favoured simply because its pre-existing governance structure closely aligned with the preferences of the euro area's core members. The retaining of intergovernmental control of lending policy at the IMF also enabled the Fund to minimize the risks of forum-shopping between multiple supervisors, given that Germany and France retained vetoes in both European institutions and the IMF.

Delegating enforcement and lending power to the IMF also fit with the preferences of a number of other European powers. France's role and prominence on the Executive Board is similar to that of Germany - both are part of the 'G5' of single-constituency members - and France was thus able to play a far greater role than on the European Council or Commission. Most interesting was the 
UK's preference for delegation; though not a euro member, Britain's position as one of the centres of European finance gave it significant weight in the resolution of issues surrounding the financial crisis. Where the British government had stridently opposed greater IMF-EMU cooperation in the 1990s, the UK was also among the earliest European states to advocate for the IMF's involvement in emergency lending and crisis management, doing so at a February 2010 Euro Summit (Hodson 2015, 586). However, this shift in preference is consistent with Moravcsik's analysis of the preferences of the British government during Maastricht negotiations, where the UK generally opposed the deepening of economic integration, but also sought to avoid being shut out of decisionmaking fora or material benefits (Moravcsik 1998, 417-419). Viewed in this light, the UK's insistence that the IMF's technical expertise and crisis management experience were necessary can be viewed as partly functional, but also as a means of guaranteeing British input on European governance through their single seat on the IMF Executive Board.

\section{Assessing Alternatives: IMF Agency and Entrepreneurship}

But what of the role the IMF itself played in expanding its role in euro area governance? At both the executive and management levels, the Fund has a long history of engaging in competencemaximizing behaviour: during Michel Camdessus's tenure as Managing Director, efforts were made to expand the IMF's Articles of Agreement to include a commitment to capital account liberalization in the Fund's mandate. At varying points, the IMF has also undergone substantial shifts in policy preferences and lending behaviour, be it the expansion of conditional lending facilities in the 1990s or the move towards national 'ownership' of policy reform in the 2000s. At the onset of the global financial crisis, the Fund was seen to have worked to reassert its role in global financial governance, acting effectively to disburse emergency lending in Asia and Eastern Europe to contain financial panic. In relation to Europe, the IMF's staff had worked throughout the 1990s to expand the Fund's oversight role within the euro area, even under the restrictions placed on such expansion by Anglo-German opposition to a greater IMF-EMU relationship (see Broome 2013). Given the prior attempts to deepen IMF involvement in Europe, it is possible that the Fund, seeing an opportunity to upset the status quo of European governance, actively worked to integrate itself into that framework.

There are several barriers to assessing the extent to which the IMF's leadership and staff consciously exploited an opportunity to play a larger role in European governance. Chief among them is the difficulty of accessing the contents of Executive Board and staff meetings; Board minutes remain classified for 3-5 years, while records related to "Institutional Archives" are classified for two decades. As such, a clear picture of the IMF's internal politics during the onset of the euro crisis is only beginning to emerge, and there is little scholarship on the Fund's inner dynamics during the period. However, there is institutional behavioural evidence to suggest that the IMF may have been engaging in this type of mandate expansion in the early period of the financial crisis. In its published reviews of both the Hungarian and Latvian bailouts, the IMF consistently sought to portray itself as a more credible actor than the Commission in the realm of economic surveillance and crisis management. In discussing Hungary, the IMF's review of its own lending programme suggested that "the EU's governance procedures resulted from a lack of flexibility and insufficient haste when it came to crisis monitoring" (International Monetary Fund 2011,35). The IMF's review of the Greece Standby Arrangement was even more damning, arguing that "the Commission has enjoyed limited success with implementing conditionality under the SGP, and had no experience with crisis management" (International Monetary Fund 2013, 31). 
The unwritten implication of "unlike the IMF" hangs heavy over both reviews, suggesting an attempt by the Fund to frame its own expertise as a vital component of any future lending and crisis management within Europe. The extent to which these assessments represented a conscious effort by the IMF to finish what it had started in 1993 is difficult to evaluate, but is an avenue of research that, as archival records of Executive Board and internal meetings are gradually declassified, is worthy of further examination.

The role of Dominique Strauss-Kahn in the European crisis is also notable - considered one of the 'founding fathers' of the Euro, Strauss-Kahn's efforts at supranational entrepreneurship "far exceeded" those of Commission President Jose Manuel Barroso in the early stages of the euro crisis (Hodson 2015, 589-590). In April 2009, Strauss-Kahn called for Central and Eastern European countries to adopt the euro, irrespective of whether they met the convergence criteria, proposed the creation of a Bank Resolution Authority in 2010, endorsed a system of fiscal transfers within the EMU, and "vocally supported" both the Banking Union and SSM (ibid.). Based on interviews with members of the IMF Executive Board, there is also some evidence that StraussKahn and the IMF's senior management sought to override the concerns of some Executive Directors about becoming involved in euro area lending and surveillance. Again, the ability to evaluate the motives and strategies of the Fund's management in a methodologically rigorous manner is constrained by the limited access to necessary data, but is another avenue of research to pursue as such information becomes declassified.

The IMF's gradual integration into the framework of European governance presents us with a similarly mixed assessment of the scale of policy change that has occurred. For the IMF, the shift as a result of the European Stability Mechanism was not paradigmatic in nature. Rather, the Fund simply extended to Europe the sorts of lending, surveillance, and monitoring functions that it had carried out in the global south in the 1980s and 1990s. From the IMF's perspective, the reasons for this change were largely functional - there was no need for a substantial Fund role in Europe until Europe was the epicentre of economic crisis. However, from the perspective of Europe, the role accorded the IMF by the ESM is a fundamental shift in the operation of European economic governance. Given past state and institutional preferences for resolving policy problems internally, the decision to delegate surveillance and enforcement power to a non-EU institution was a radical break from the Maastricht Treaty and the prior history of European governance.

There are a number of implications for our understanding of the IMF-EMU relationship, both for why the relationship evolved, and for what that evolution might mean in the future. Clearly, the onset of the euro crisis drove the realignment of the IMF-EMU relationship, provoking the deep systemic uncertainty necessary to re-evaluate the IMF's role within European governance - the Fund had been sidelined on the presumption that the Commission's mechanisms of oversight and enforcement were sufficient, and the crisis overwhelmingly revealed that to be false. Consequently, the decision to involve the IMF in European governance can also be seen as a function-driven one. The Fund offered a policy toolset that the EMU's members felt was needed, and the erosion of the credibility of existing governance frameworks meant that drafting the IMF into the EFSF, EFSM, and ESM was the preferred option. Moreover, the Fund's governance structure fit with the outcomes of ESM bargaining; decisions on lending remain in the hands of the IMF's members, while enforcement and surveillance is carried out autonomously. If the Fund's toolset and institutional structure had been seen as unnecessary or undesirable in 1993-94, by 2012, the IMF's structure and functions were seen to align with what European leaders wanted from a supranational system of crisis management and economic surveillance. 


\section{Conclusion}

What this means for the future of the EMU-IMF relationship depends on a number of factors. In part, future involvement by the IMF in euro area governance is contingent upon the Fund's functions still being required. The language of the ESM Treaty seems to allow for this sort of replacement. The Fund is called upon to participate in lending programmes and reform oversight where necessary, and much of the IMF's work in bailouts to Greece, Portugal, and Spain has relied upon deliberate ambiguity to involve the expertise of the IMF's technocratic staff. The nature of the Fund's de facto position as an EMU institution also makes the development of internal alternatives an attractive policy option. The IMF is not bound by EU Treaty law or required to serve the interests of the European Monetary Union, nor is it subject to oversight by the Commission, Council, or European Parliament.

Given the lack of binding oversight from other European institutions, the IMF's continued involvement in euro area governance is also contingent on the Fund playing the role that euro members want it to. Indeed, previous disagreements between IMF and Commission leadership have led to such an alignment being questioned. In 2013, the IMF published a scathing ex-post facto analysis of fiscal austerity in Greece, noting that the terms of the Troika's lending programme had actually worsened the fiscal and economic outlook for Greece. The Commission's response was predictably defensive, with the Commissioner for Economic and Monetary Affairs criticizing the IMF for "attempting to wash its hands and throw the dirty water on the Europeans" (Hodson 2015, 592). In June 2015, the IMF threatened to withdraw from participation in lending to Greece altogether, over deep disagreements concerning the possibility of debt relief for insolvent euro members; continued discord over the terms of future tranches of lending to Greece have repeatedly delayed the implementation of ESM programmes (Spiegel and Chazan 2016). Were such disagreements over the necessity of austerity, or the structure of programme monitoring and surveillance, to deepen, this would likely disrupt the IMF's position as an external participant in the governance of the euro. The IMF's Independent Evaluation Office (IEO) has also voiced concern that the IMF's collaboration with the Commission and ECB subjected its technical analysis to undue political influence, and its 2016 report on lending during the euro crisis recommended developing clearer policies on cooperation with regional financial arrangements (i.e., the ECB) and preventing policy manipulation by external political concerns (Independent Evaluation Office 2016, 2-3).

The question of the IMF's continued participation as integrated supervisor within the euro area has been made more relevant by recent events. Though the Troika's policy approach has not changed significantly, the anticipated conclusion of Greek bailout programmes in 2018 is likely to reduce the perceived need for IMF involvement in euro area governance. A strengthening European economy has also reduced the sense of urgency that necessitated building on existing governance approaches from 2009-11. More significantly, the prospects for significant EU reforms markedly improved in 2017. The election of Emmanuel Macron in France and growing support amongst German political leaders for turning the ESM into a European Monetary Fund may lead to the development of internal crisis management frameworks and institutions that eliminate the need for future IMF participation in euro area oversight. Where an alignment of preferences among Europe's core economies led to the involvement of the IMF during the euro crisis, a similar alignment may render it irrelevant in the years to come. 


\section{REFERENCES}

Broome, Andre. 2013. "The Politics of IMF-EU Cooperation: Institutional Change from the Maastricht Treaty to the Launch of the Euro." Journal of European Public Policy, 20 (4): 589-605.

Chwieroth, Jeffrey. 2008. Capital Ideas: The IMF and the Rise of Financial Liberalization. Princeton, NJ: Princeton University Press.

Eurogroup. 2011. "Statement by the Eurogroup.” Brussels: Council of Ministers of the European Union. July 2.

European Council. 2012. "Spain: Memorandum of Understanding on Financial Sector Policy Conditionality." July 20.

European Stability Mechanism. 2012. Treaty Establishing the European Stability Mechanism. 2 February. https://www.esm.europa.eu/sites/default/files/20150203 _ esm treaty _ en.pdf

Francis, David. 2010. "Merkel praised in Germany for hard line on Greece debt crisis." Christian Science Monitor, March 26.

Fuhrmans, Vanessa, and Sebastian Moffett. 2010. "Exposure to Greece Weighs on French, German Banks.” The Wall Street Journal, February 17.

Glencross, Andrew. 2014. "The Euro Area Crisis as a Challenge to Democracy and Integration." Orbis, 58(1): 55-69.

Hall, Peter A. 2012. "The Economics and Politics of the Euro Crisis." German Politics, 21 (4): 355-371.

Hodson, Dermot. 2011. Governing the Euro Area in Good Times and Bad. New York: Oxford University Press.

- 2015. "The IMF as a de facto institution of the EU: A multiple supervisor approach." Review of International Political Economy 22 (3): 570-598.

Independent Evaluation Office. 2016. "The IMF and the Crises in Greece, Ireland, and Portugal." IMF Independent Evaluation Office.

International Monetary Fund. 2011. "Hungary: Ex Post Evaluation of Exceptional Access under the 2008 Stand-By Arrangement." IMF Country Report No. 11/145.

—. 2013. "Greece: Ex Post Evaluation of Exceptional Access under the 2010 Stand-By Arrangement." IMF Country Report No. 13/156.

Joyce, Joseph. 2013. The IMF and Global Financial Crises: Phoenix Rising? Cambridge: Cambridge University Press.

Lutz, Susanne and Matthias Kranke. 2014. "The European rescue of the Washington Consensus? EU and IMF lending to Central and Eastern European countries." Review of International Political Economy, 21 (2): 310-338. 
Mayer, Thomas. 2012. Europe's Unfinished Currency: The Political Economics of the Euro. London: Anthem Press.

Moravcsik, Andrew. 1993. "Preferences and Power in the European Community: A Liberal Intergovernmental Approach.” Journal of Common Market Studies, 31 (4): 473-524.

- 1998. The Choice for Europe: Social Purpose and State Power from Messina to Maastricht. New York: Cornell University Press.

Panagiotarea, Eleni. 2013. Greece in the Euro: Economic Delinquency or System Failure? Colchester: ECPR Press.

Rato, Rodrigo. 2011. "A new role for the IMF in the aftermath of the crisis." European View, 10 (1): $87-94$.

Reuters. 2011. "Italy calls for euro bonds, UK backs fiscal union.” August 13.

Rogers, Chris. 2012. The IMF and European Economies: Crisis and Conditionality. New York: Palgrave Macmillan.

Schimmelfennig, Frank. 2015. "Liberal Intergovernmentalism and the euro area crisis." Journal of European Public Policy, 22 (2): 177-195.

Schwarzer, Daniela. 2015. "Building the euro area's debt crisis management capacity with the IMF." Review of International Political Economy, 22 (3): 599-625.

Spiegel, Peter, and Guy Chazan. 2016. "EU, IMF attempt to bridge increasingly bitter Greece bailout rift.” Financial Times, March 6.

Tallberg, Jonas. 2003. European Governance and Supranational Institutions: Making States Comply. New York: Routledge.

Teschner, Julia. 2000. "No longer Europe's Europhiles? Euroscepticism in Germany in the 1990s." Journal of European Integration, 22 (1): 59-86.

Vreeland, James. 1999. “The IMF: Lender of Last Resort or Scapegoat?” International Studies Association Annual Meeting. 
Published by the Centre for European Studies at Carleton University, Ottawa, Canada Available online at: journals.carleton.ca/rera/index.php/rera

RERA is an electronic academic peer-reviewed journal that publishes graduate, post-graduate, and young scholarly works. Topics relate to the European Union, its Member States, the former Soviet Union, and Central and Eastern Europe. The journal is a joint project supported by the CanadaEurope Transatlantic Dialogue - a cross-Canada research network supported by the Social Sciences and Humanities Research Council of Canada (SSHRC) — along with the Institute of European, Russian and Eurasian Studies (Carleton University) and its associated research unit, the Centre for European Studies.

RERA aims to provide an accessible forum for research, to promote high standards of research and scholarship, and to foster communication among young scholars.

\section{Contact:}

Carleton University

The Centre for European Studies

1103 Dunton Tower

1125 Colonel By Drive

Ottawa, ON K1S 5B6

Canada

Tel: +01 613 520-2600 ext. 3117; E-mail: rera-journal@carleton.ca

\section{Creative Commons License}

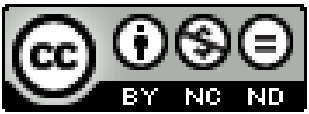

creativecommons.org/licenses/by-nc-nd/3.0

This Working Paper is licensed under a Creative Commons Attribution-Non-CommercialNo Derivs 3.0 Unported License (CC BY-NC-ND 3.0).

Articles appearing in this publication may be freely quoted and reproduced, provided the source is acknowledged. No use of this publication may be made for resale or other commercial purposes.

ISSN: $1718-4835$

(C) 20158 The Author(s) 